Ilmenau University of Technology

Institute of Economics

Ilmenau Economics Discussion Papers, Vol. 25, No. 122

Does Music Quality Matter for Audience Voters in a Music Contest

Oliver Budzinski, Marie Kohlschreiber, Björn A. Kuchinke \& Julia Pannicke

März 2019

Institute of Economics

Ehrenbergstraße 29

Ernst-Abbe-Zentrum

D-98 684 Ilmenau

Phone 03677/69-4030/-4032

Fax 03677/69-4203

http://www.wirtschaft.tu-ilmenau.de

ISSN 0949-3859 


\title{
Does Music Quality Matter for Audience Voters in a Music Contest?
}

\section{Oliver Budzinski*, Marie Kohlschreiber ${ }^{+}$, Björn A. Kuchinke*, Julia Pannicke ${ }^{x}$}

\begin{abstract}
There are numerous studies analyzing factors of success in media-broadcasted artistic contests, especially music competitions. However, one factor that is generally neglected in the literature is the quality of the artistic performances (i.e. "music quality"). In this paper, we approach this research gap by developing two novel concepts of music quality and by employing unique measures during the empirical analysis of a popular German music television contest in order to analyze how different dimensions of the music and performance quality influences the final voting results. We use the complete historical voting dataset of the music contest from its inception in 2005 until its last broadcast in 2015, collecting 2,816 observations in total. First, we define dimensions of "objective quality" according to insights from musicological research/literature. Second, we conceptualize dimensions of "subjective quality" because music preferences may be subjective and are not necessarily based on how experts' define "good" music. We measure these subjective dimensions in an experimental setting with students from two German universities. Our analysis shows that different quality dimensions affect the outcome of voting results in different ways and not all quality dimensions reveal themselves as significant. In general, subjective quality dimensions turn out to be more relevant than objective ones. The differentiated results of our analysis support the value of our approach to deconstruct quality into different dimensions and test them individually.
\end{abstract}

JEL-Codes: L82, Z10, C50

Keywords: music contest, cultural economics, media economics, econometric analysis, success factors, voting bias, music industry

\# Professor of Economic Theory, Institute of Economics \& Institute of Media and Mobile Communication, Ilmenau University of Technology, Germany, email: oliver.budzinski@tu-ilmenau.de.

+ Researcher, Media Economics, Faculty of Media, Bauhaus-University Weimar, Germany, email: marie.kohlschreiber@uni-weimar.de.

Professor of Media Economics, Faculty of Media, Bauhaus-University Weimar, Germany, email: bjoern.kuchinke@uni-weimar.de.

x Ph.D. Economics, Associate Researcher, Economic Theory Unit, Institute of Economics, Ilmenau University of Technology, Germany, email: juliapannicke@googlemail.com.

An earlier version of this paper was presented at the $13^{\text {th }}$ World Media Economics and Management Conference in Cape Town/South Africa (May 2018). We thank all discussants for their helpful comments. Furthermore, we thank Sophia Gaenssle, Barbara Güldenring, and Milan Lange for valuable assistance during the research project. We are particularly grateful to music expert Frank Zenses. He has studied guitar, song analysis and harmony analysis at the Munich Guitar Institute. He received his diploma in 2000. Since then he has been working as a professional musician. We also thank all the students from Ilmenau and Weimar who participated in the assessment sessions. 


\section{Introduction}

When it comes to cultural goods, like music, it is a common prejudice against the tastes of the masses that "quality" is irrelevant or even detrimental to success. However, it remains an open question if such a claim is supported by empirical evidence. While both cultural and media economics have developed a theory of success factors in music contests and provided empirical evidence for many of the factors, to our best knowledge, we are the first to provide a comprehensive analysis of the role of different concepts of music quality in such contests. For this purpose, we analyze a unique dataset stemming from a national music contest in Germany where voting by the television audience solely determined the final ranking (annual contest from 2005 to 2015; in total 2,816 observations). For all contributions to this contest, we collected - next to all the usual non-quality success factors used in the literature so far - a variety of possible quality indicators.

One of the reasons why the literature has been reluctant to analyze quality directly lies in the difficulty to operationalize (and measure) concepts of "quality", especially when it comes to cultural goods. Therefore, we develop and employ two novel concepts of "music quality" (see section 2 for details): First, we define dimensions for an "objective quality" according to insights from musicological research and literature, such as change in harmony, refrain-tones of music or beats per minute. We measured these dimensions by expert assessment of all contest contributions. Second, we conceptualize a "subjective quality" because we are analyzing popular music and, here, preferences may relate to subjective characteristics such as an expressive singing voice or feelings and emotions when listening to the song or watching a video of the performance. In order to make these subjective dimensions measurable, we asked students from different universities in Germany to evaluate each performance of the contest. Together with control variables for the usual non-quality success factors from the literature, we include these novel variables as independent variables in an empirical model, which aims at explaining the respective success of the performances.

Several research papers in economics have addressed the issue of success factors in music contests. In the economics of superstardom, superior talent combined with a 
low substitution elasticity between marginally different talent levels are hypothesized to determine success (Rosen 1981; Borghans \& Groot 1998). Such a higher-level talent may be understood to represent some sort of "quality". However, talent may refer to very different dimensions, i.e. talent for singing, talent for composing, talent for performing, etc. When an audience is tasked with judging contestants in a music contest, their judgment may rest on different dimensions and/or a mix of them. On the one hand, a multi-dimensional competition may distract from quality because an uninformed and non-expertise audience may struggle to identify superior talent and focus on other dimensions (like the looks of the artist or likability) instead, leading to low-quality contest winners (Franck \& Nüesch 2007). On the other hand, the multidimensional character may intensify competition among the contestants, improving overall performances in all dimensions (Amegashie 2009). Furthermore, the experience good character of cultural goods together with risk-averse consumers creates strong path-dependencies of success, i.e. former success determines future success (MacDonald 1988). Self-reinforcing effects also promote success through bandwagon effects (Leibenstein 1950) and an accumulation of consumption capital (Stigler \& Becker 1977). Consumers derive utility from different sources (Adler 1985, 2006): next to the (i) enjoyment of listening to the music and (ii) the accumulation of knowledge (individual expertise) about the artists and the music, consumers may benefit from (iii) communication with others about the music and its performers (commonality effect) and (iv) enjoying media coverage of their favorite music and artists. While (ii) further fuels path-dependency in the consumption of similar music or music from the same artist, (iii) and (iv) hint to network effects: the more consumers like an artist or a piece of music, the higher the probability is to find communication partners or media coverage about him/her/it.

Empirical economic studies have analyzed different music contests in order to identify factors determining the outcome. Many studies have focused on the Eurovision Song Contest (inter alia Yair 1995; Haan et al. 2005; Clerides \& Stengos 2006, Fenn et al. 2006; Ginsburgh \& Noury 2008; Spierdijk \& Vellekoop 2009; Kokko \& Tingvall 2012; Budzinski \& Pannicke 2017a, 2017c; Mantzaris et al. 2018a, 2018b) but also the Queen Elizabeth Music Contest (Flôres \& Ginsburgh 1996; Glejser \& Heyndels 2001; Ginsburgh \& van Ours 2003) and so-called casting shows like Pop Idol or X- 
Factor (Lee 2009; Heizler \& Kimhi 2012). Furthermore, some of us have presented earlier studies of the Bundesvision Song Contest (Pannicke 2016, 2018; Budzinski \& Pannicke 2017a, 2017b), which will be put into focus in this paper as well. A related branch of literature has studied success factors in music charts (inter alia, Hamlen 1991, 1994; Crain \& Tollison 2002; Giles 2006, 2007a, 2007b; Asai 2008; Filimon et al. 2011; Fereira \& Waldfoge/2013), of rock concert revenues (Krueger 2005) as well as of online streaming, views and subscriptions with respect to various platforms (Bauer \& Sched/2018; Budzinski \& Gaenss/e 2018). These papers empirically identify a variety of influencing factors on success like the order of performances (Ginsburgh \& van Ours 2003), solo vs. group and gender (Glejser \& Heyndels 2001; Haan et al. 2005; Giles 2007), previous popularity and especially media presence (Budzinski \& Pannicke 2017b), snowball effects (Chung \& Cox 1994; Giles 2007a); visual and aesthetic appearance (Hamermesh \& Biddle 1993; Biddle \& Hamermesh 1998; Tsay 2013), preferences regarding skin color and ethnic origin (Lee 2006) as well as social networks (Heizler \& Kimhi 2012).

Furthermore, with a view to contests where the voting (television) audience considerably influences the results, the literature establishes empirical evidence for biased audience voting behavior based upon geographical and cultural closeness, linguistic and religious factors (inter alia, Haan et al. 2005; Ginsburgh \& Noury 2008; Lee 2009; Spierdijk \& Vellekoop 2009; Heizler \& Kimhi 2012; Budzinski \& Pannicke 2017a), i.e. the audience mixes performance-related voting dimensions with cultural elements. The closest to our research are Hamlen (1991) and Gergaud et al. (2012). Hamlen (1991) analyzes the relationship of the "harmonic quality" of a singer's voice with charts success. He finds that record sales under-proportionally increase with so-measured voice quality. However, Schulze (2003) casts doubt on whether harmonic voice really determines success in popular music, pointing to the role of the quality of the song, which was not measured in Hamlen's studies. Gergaud et al. (2012) analyze the influence of perceived talent, intelligence and beauty according to a survey on 49 celebrities from different categories of entertainment industries (with 7 from the music industry). They find that perceived talent and perceived intelligence are more important than perceived beauty. 
Our research significantly extends the existing literature by using a much broader set of quality indicators that cover different aspects of a popular music performance (including voice and song as well as other performance attributes; see the following section 2 for more details). In contrast to Gergaud et al. (2012), we analyze 2,816 observations from the music industry only, covering both more and less successful artists. Furthermore, by analyzing an audience-voting based music contest instead of music charts, we are comparing more immediate and direct audience reactions with each other.

\section{Concepts of Music Quality}

We want to emphasize that we do not intend to operate with a general definition of "quality" of (pop) music. Very obviously, a high quality song for one person can be a low quality song for someone else. Consequently, we do not aim to define and measure "quality" by a single variable. Instead, we assume that the term "quality" can refer to very different dimensions, so that "quality" becomes a complex construct involving both objective and completely subjective dimensions. We understand an "objective" dimension to refer to something that is intersubjectively measurable like, for instance, beats-per-minute, whereas a "subjective" dimension refers to something that cannot be assessed in an intersubjective way, like the emotional effect of a song on the listener. Furthermore, we call the intersubjectively measurable dimensions "objective" because every music expert would arrive at the same judgment, i.e. they do not involve any scope for subjective assessments. Keep in mind, however, that it remains subjective in both cases whether an individual listener prefers a certain parameter value or not.

In economics, the complexity of quality often leads to an indirect treatment of this very relevant - issue: a good that receives high demand is ceteris paribus viewed to be of a higher quality in the sense of matching the (subjective) preferences of the consumers in a superior way. We aim to disentangle the blackbox character of this view with regard to pop songs by identifying (i) a set of objective dimensions and (ii) a set of subjective dimensions - both derived from musicology research (and each requiring different measuring methods). We assume "quality" to consist of a combination of these dimensions, which we, therefore, refer to as quality dimensions. This 
does not imply, however, that any single quality dimension in itself or alone is a good representation of the overall term "quality". Furthermore, we do not claim that our total set of quality dimensions is complete. Nevertheless, for reasons of research stringency, we stick to the dimensions we could derive from the respective theories.

\section{Objective Quality}

Kramarz (2014) shows that the success of pop songs is based on certain design features or song structure characteristics, respectively. In addition, by surveying pop listeners and, for instance, measuring their brain activity, he reveals insights into the attendant harmony sequences that prove to be crucial to the success of a musical piece. A hit usually combines elements of proven working methods with constructs of individual original creativity. Based on Kramarz' and also Von Appen's (2007) reflections and research results, we derived different objective quality dimensions.

Overall seven quantifiable dimensions have been identified, which significantly contribute to music being appealing to consumers. An example is the criterion change in harmony. This means if a song is written in "f", chords like " $e$ " or " $g$ " fit this harmony. Regarding successful songs very often no change in harmony is included or the harmony change is applied to count time 1. According to musicology research, the listener experiences a change of harmony as annoying, in particular if it does not take place on count time 1. In other words, no change in harmony or the change in harmony (on count time 1) is an objective quality feature and leads to greater success (Schmidt \& Terhag 2010: 25). The music expert marks "yes" if there is no change in harmony or if the harmony changes on count time 1. If chords are played in a song that do not fit this harmony and the harmony does not change on count time 1 the music expert marks "no".

It is the same thing with the criterion highest vocal sounds in the chorus. Music theory says that the highest vocal sounds should be in the chorus because this appeals to the consumer and, in this sense, indicates a high quality. With the refrain, the climax of the song is often reached and the so-called hook-line begins. Exactly at this point, respectively in this part, there is often a rising pitch in the vocal melody (Riedermann 2012: 51). So, the music expert analyzes whether the highest vocal sounds are in the chorus or not ("yes" or "no"). 
Furthermore, the expert counted out the beats per minute. If the beats per minute are in between 80 and 110 then the music expert marks "yes" (Riedermann 2012: 51). If the song is slower or faster he marks "no". According to musicology theory, "no" implies that the music is less-appealing to the ears of the consumer and, thus, of lower quality (but the expert is only used to state the fact of the number of beats per minute). A beat per minute between 80 and 110 also corresponds to the rhythm of the human heart and is, therefore, usually perceived as pleasant (see also Biamonte et al. 2011).

Moreover, theory works out that a song structure $A B A B C B$ fuels success. A denotes verse, $B$ denotes chorus and $C$ denotes a different part like, for instance, a guitar solo. One reason for this is that the listener likes this structure because he/she is familiar with it. Another reason is that this "dramaturgy" obviously corresponds to the preferences. So again, it was up to the music expert to analyze what structure the song had.

The intro has several functions and is strongly influenced by the desired target group of the song. The intro of a song that is to be released as a single, for example, is to be designed according to commercial specifications. It should not be longer than a few seconds and must arouse the interest of the audience (Rooksby 2003: 64; Kramarz 2014: 84). If these dimensions are fulfilled, the song performs better in these quality dimensions compared to songs where the running time of the intro is longer than 10 seconds.

The same applies to the criterion change in speed. Changes in speed are more likely to be deemed annoying. The flow of the music is supposedly lost. That is why songs without a tempo change are rated better and are more successful.

The last criterion is instrumentation. The standard instrumentation of pop songs is assumed to be drums, bass, guitars, piano/keyboards, brass and any kind of samples. This instrumentation is hypothesized to make a song more successful than if "unusual" instruments are added, for example a violin or a clarinet. This can be explained by the fact that unusual, less used or less familiar instruments are perceived as disturbing. 
Keep in mind that we call these factors from music research "objective" dimensions because they are objectively measurable. Whether they really make a song more successful in the context of our music contest, i.e. really appeal to the listener in the conjectured way and are sufficiently relevant for him/her, is up for the empirical analysis in this paper to determine.

\section{Subjective Quality}

Furthermore, all songs have been examined with respect to the dimensions confident (strong) voice, charismatic and authentic presentation/performance, performance stylistically closed and song fits the image of the artist. According to music theory, these criteria have a positive effect on the quality of the songs. Theory conjectures that the success of a song increases with these quality dimensions of this song.

We call these dimensions "subjective" because it cannot be identified and determined in an objective way whether a performance was charismatic or true to the artist's image. One may think the performance is stylistically closed, someone else may say it is not; there is no objective criterion for measuring a stylistically closed performance. However, a performance or elements of the song that are subjectively perceived as inappropriate or disturbing, lowers the attractiveness of the production (Kramarz 2014: 253). While a certain variety may prevail in the lineup of the individual singers, even small deviations from the harmonically correct tone are criticized more or less strongly (Kramarz 2014: 137-138). Furthermore, the (historical) image of the artists influences the musical assessment: the musical presentation will be rated more positively if the performance is accompanied by a corresponding image (Cohrdes et al. 2012: 193). An authentic personality with a corresponding charismatic expressiveness also contributes to a positive overall assessment (Von Appen 2003: 111). The charisma of an individual directly affects the perception of the respective artist, the performance and the song itself. Subjective feelings and emotions play the important role in these dimensions of music quality. Feelings and emotions depend much more on the individual. Intrinsic values, personal qualities and normative ethics play an important role by answering our "subjective dimensions". 
Based on Giomo (1993), we further identified six musical mood dimensions: softness, intensity, unpleasantness, pleasantness, solemnityand triviality. We call these dimensions "subjective" because the assessment of mood cannot be done in an objective way. Note that the individual assessment of a song or performance as, for instance, softness differs from whether this individual likes the song: some may like soft music, others not. While the first part (assessment whether a song is soft) is part of our measured quality dimension, the latter part (is softness correlated with success) is part of the empirical analysis. While the term softness is representative of emotional states such as peaceful, melancholy, dreamy, restful, yearning, pensive and calm, intensity implies the adjectives energetic, agitated, lively, stormy, unrestrained, uneasy, violent and wild. The term unpleasantness expresses impulses like dramatic, frightening, serious, dark, ponderous, anguished or fateful, whereas pleasantness is synonymous with glad, cheerful, elated, playful, airy and light. Solemnity is used to verbalize adjectives like majestic, grand, powerful, dignified, solemn and serious. Triviality represents impressions like light-hearted, casual, trivial and commonplace (see also Geiger 2003).

Furthermore, the subjective value criteria originality, novelty, boredom and variety, formulated by Von Appen (2007), mark facets of our interest in music that attract our attention. According to the value originality, songs are recognized as original, if you can attribute an individual and unique style to it; contributions that are considered particularly innovative are attributed to the category novel. Boredom refers to performances that cannot maintain the attention of the audience. If the respective musical contribution is subjectively perceived as very varied, for example by changes in tempo or different emotional moods, it is assigned to the corresponding eponymous category (for more aesthetic value dimensions of a musical work see Child 2000).

The subjective criteria mentioned in the last two sections softness, intensity, unpleasantness, pleasantness, solemnity, triviality, originality, novelty, boredom and variety) are well known and discussed in musicology. However, there is no clear theoretical classification or analysis. At best, (more or less convincing) plausibility considerations can be found. Furthermore, the available empirical studies do not always find a clear causality. The easiest way to do this is the criterion boredom, because it is neither 
plausible nor empirical work that a boring piece of music shows a high quality for listeners and therefore also has better chances of performing in a music contest. So there is a negative correlation to suspect between the boredom criterion and quality. In contrast, intensive pieces should be judged rather positively by the listener, i.e. with a higher quality, because intensive pieces of music touch the listener more than non-intensive songs. The variety criterion, on the other hand, is unclear. Listeners seem to prefer simple songs with a short intro and well-known song structure (objective criteria), and attribute higher quality to them. However, there should be some variations in songs to be successful, otherwise songs will not be different. Where exactly the right degree of variation is, however, is unclear. In the following empirical analysis, it is therefore important to analyze the respective causality. Thus, there will be a contribution to the scientific discussion about these criteria.

\section{Bundesvision Song Contest: Background}

The Bundesvision Song Contest (in short: BSC), whose name is a portmanteau word made up of the prefix "Bundes" in relation to the "Bundesrepublik Deutschland" and the "Eurovision Song Contest", was a German music competition contest based on the model of the international music competition contest "Eurovision Song Contest" (ESC). The first BSC was held on February, $12^{\text {th }}, 2005$ in the German state North RhineWestphalia. The BSC ended after 11 successful years when its creator retired from television in 2015. The main objective of the contest is to select a musician winner at the end the show. For this purpose, 16 German musicians compete against each other, each representing one of the 16 German States. The participants of the contest perform in randomized order. Among the artists are both well-established musicians as well as newcomers. The winner of the contest is decided by the audience that vote for their favorite artist at the end of the show via SMS voting and/or telephone calls. Similar to the ESC, the votes are counted up individually by each German state. Accordingly, the artist who acquires the highest number of telephones calls and messages within a German state receives the highest number of twelve points. The second place receives ten points and the third eight points. The following ranks receive decreasingly down to one point with nine and eleven points not being awarded. The 
winner is the artist that achieves the highest number of votes cumulated across all states. $^{1}$

\section{Empirical Analysis}

\subsection{Estimation Model}

This paper investigates the correlations between objective and subjective quality dimensions, on the one hand, and the total number of points achieved by a song in a music contest, on the other hand. The subject matter of this empirical analysis is the Bundesvision Song Contest. Therefore, we collect the complete historical voting data of the contest in order to test our research questions. We aggregate the data of the song contest from its first show in 2005 until the last show in $2015 .^{2}$ The results of all votings are published online by ProSiebenSat.1 Group, which is one of the most popular independent media companies in Europe. These voting data characterize each number of points the voters in each German state awarded every artist of the contest each year. Because in every contest 16 different performers compete against each other, we get 2,816 observations in total. We consider every single point given from voters within each German state $A$ to each performer B for every single year from 2005 to 2015. Each German State A is observed during T $=11$ time periods. Thus, our balanced panel dataset consists of repeated observations over time. It is assumed that each German state is independent of all other German states, but correlations between observations relating to the same German state are legitimate. We test our research question of quality dimensions (objective and subjective) influencing the voting results through our panel data model. The dependent variable is defined as the given POINTS ${ }_{A B, t}$ from voter $A$ to the performer $B$ per year within the complete period from 2005 to 2015.

In order to deal with our panel dataset, we run 3 different models:

- model 1: fixed effects model

- model 2: Poisson fixed effects model

- model 3: zero-inflated Poisson model 
First, POINTS ${ }_{A B, t}$ are treated as a continuous response variable (inter alia, Ginsburgh \& Noury 2008; Pannicke 2016; Budzinski \& Pannicke 2017a). After running a Hausman test comparing fixed with random effects, we estimate our first model by linear methods taking into account state- and time-fixed effects (model 1). We are interested in explaining the impact of variables (objective and subjective quality of the performance) that vary over time. Fixed-effects models remove the effect of timeinvariant variables like cultural, religious and geographical aspects as mentioned above by an individual heterogeneity term.

Because POINTS ${ }_{A B, t}$ can also be treated as count variables (points from 0 to 12), we secondly use a panel Poisson regression model (model 2) over time and over German state. The Poisson fixed effects model has been suggested by Palmgren (1981) and Hausman et al. (1984). The classic way of estimating the parameters of this model is the conditional maximum likelihood of Andersen (1970). As assumed for Poisson models where our dependent variable POINTS $\mathrm{AB}_{\mathrm{t}}$ is a count variable, the question arises whether the number of zeros may appear excessive. Zero-inflated Poisson models are considered to handle situations where an excessive number of zeros occur for a disproportionate number of individuals. In the last years, zero-inflated models have become very popular in this field of research (inter alia, Lord et al. 2005; Hu et al. 2011; Thamm 2012).

In our dataset, where our dependent variable is defined as the "given points from voter $A$ to the performer $B$ " an immense majority of performers have a value of 0 . As illustrated in the histogram below, the shape of distribution ("over-dispersion") may suitable for running a zero-inflated Poisson model. 
Figure 1: Shape of distribution

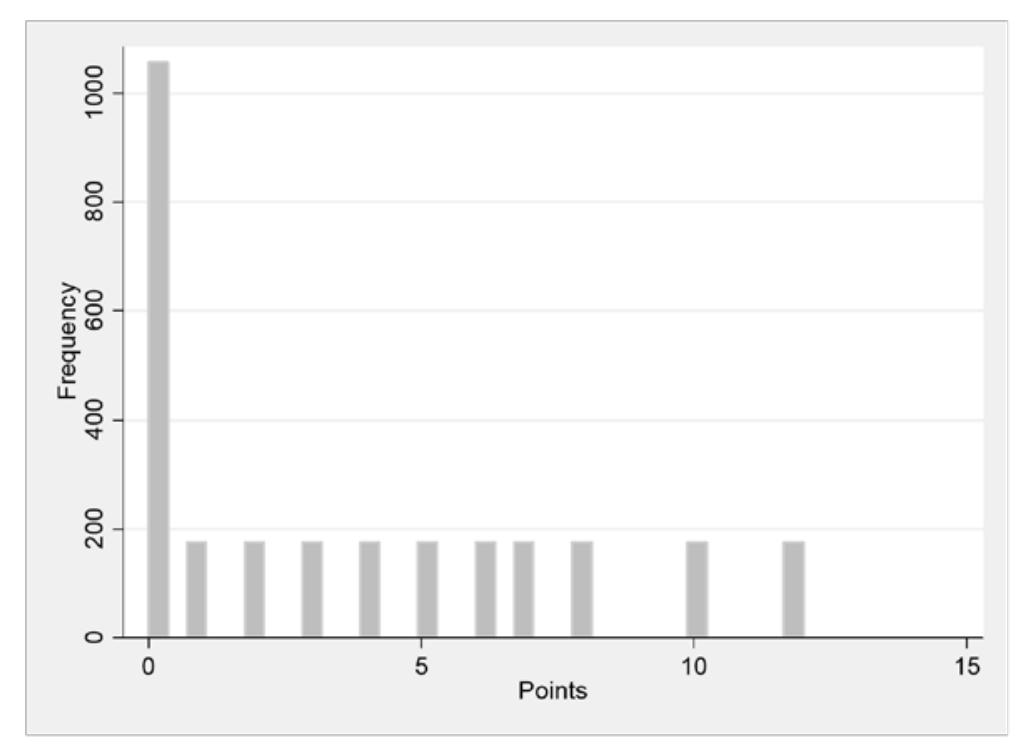

Source: Own representation.

Zero-inflated models assume that the observations of zeros are due to some particular structure in the data, "true zeros" and "excess zeros". That is the reason why zeroinflated models estimate two equations, one equation for the count model and the other equation for excess zeros (Lord et al. 2005; Hu et al. 2011; Thamm 2012). Thus, we define our third model as a zero-inflated Poisson model.

Accordingly, we define POINTS ${ }_{A B, t}$ as the response variable:

$$
\begin{aligned}
& \text { Points }_{A B, t}=\alpha_{A B}+\beta_{1} \text { Quality }_{B, o, t}+\beta_{2} \text { Quality }_{B, s, t}+X_{A B, t}+\varepsilon_{A B, t} \\
& \text { where } \\
& \text { POINTS }{ }_{A B, t}=\text { number of points given by voters } A \text { to performer } B \text { in year } t \text {, } \\
& \alpha_{A B}=\text { unknown intercept for each German state, } \\
& \beta_{1} \text { Quality }_{\mathrm{B}, \mathrm{o}, \mathrm{t}}=\text { objective quality of the performance by artist } \mathrm{B} \text { in year } \mathrm{t} \text {, } \\
& \beta_{2} \text { Quality }_{B, s, t}=\quad \text { subjective quality on average of the performance by artist } B \text { in } \\
& \text { year } t \text {, } \\
& \varepsilon_{\mathrm{AB}, \mathrm{t}}=\quad \text { error term for independent variables and } \\
& \mathrm{X}_{\mathrm{AB}, \mathrm{t}}=\text { corresponding control variables. }
\end{aligned}
$$




\subsection{Variable Description and Descriptive Statistics}

As already mentioned, many empirical studies have focused their research on the Eurovision Song Contest and the accompanying biased votings based on inter alia relations between the different countries and cultures (Yair 1995; Haan et al. 2005; Fenn et al. 2006; Ginsburgh \& Noury 2008; Budzinski \& Pannicke 2017a). As a consequence, we have to control for various independent variables in order to measure the effect of quality. We split our control variables into different categories (Budzinski \& Pannicke 2017a):

I. the quality of a song: objective and subjective quality dimensions

II. performance characteristics: for example gender, order, formation, hosting the contest,

III. popularity of the artist: media coverage and chart-positions,

IV. geographical, cultural, and confessional relationships between the German States.

\section{Dataset: Objective Quality}

Appraisals based on objective quality dimensions were conducted by an expert. This qualified professional musician examined all video contributions (full length) to those previously identified literature-based objective quality parameters (see section 2).

As can be seen from table 1, a checklist was used as an instrument of assessment for the analysis. Each of the 176 performances has been examined with respect to those dimensions by a musical expert. Initially, the title, artist, year and length of the performance were recorded. 
Table 1: Objective Quality Dimensions

\begin{tabular}{|l|l|}
\hline Criteria & Answer options \\
\hline & \\
\hline No change in harmony or the harmonies change on count time 1. & yes (1) / no (0) \\
\hline The highest vocal sounds can be recognized in the chorus. & yes (1) / no (0) \\
\hline The tempo is in the moderate range between 80 and $110 \mathrm{bpm}$. & yes (1) / no (0) \\
\hline The composition is constructed based on the scheme ABABCB. & yes (1) / no (0) \\
\hline The running time of the intro is less than 10 seconds. & yes (1) / no (0) \\
\hline There is a change in speed in the song. & yes (1) / no (0) \\
\hline $\begin{array}{l}\text { The (standard) instrumentation is composed of drums, bass, guitars, piano/ } \\
\text { keyboards, brass and any kind of samples. }\end{array}$ & yes (1) / no (0) \\
\hline
\end{tabular}

Source: Own representation.

\section{Dataset: Subjective quality}

The live performances of all 176 singers and bands who participated in the competition were published on the freely accessible website myspass.de. The individual video clips were shortened to a length of 90 seconds in order to present a representative section of music and performances to the students during their seminar. In order to measure and analyze the "subjective quality", we collected data regarding the individual music preferences of students during summer term 2017. We asked students from Ilmenau University of Technology (M.Sc.-program "Media Business") and Bauhaus University Weimar (BA-program "Media Culture") in Germany to evaluate each of the 176 clips concerning different aspects like charisma, expressive singing voice, feelings and emotions when listening to the song (see section 2). We developed an online questionnaire (umfrageonline.com), which we used as an instrument to record the subjective assessment of each student. All 176 clips have been examined by the students with respect to all determined subjective quality dimensions. To analyze the questionnaire results, descriptive and inductive statistics are used. As shown in table 2 , the questionnaire contained the following questions and possible answers. In addition, general socio-demographic features were collected, like gender, age, civil status, state of origin, degree course, major, preferred music genre and favorite musician or band. 
Table 2: Subjective Quality Dimensions

\begin{tabular}{|c|c|}
\hline Question/criteria & Answer options \\
\hline $\begin{array}{l}\text { Does the artist have a confident voice and expressive } \\
\text { vocals? }\end{array}$ & yes (1) / no (0) \\
\hline $\begin{array}{l}\text { Does the artist and its song appear authentic and char- } \\
\text { ismatic in the performance and embodiment of the } \\
\text { piece? }\end{array}$ & yes (1) / no (0) \\
\hline $\begin{array}{l}\text { Is the performance of the song stylistically closed in it- } \\
\text { self and as a whole? (Inappropriate and disturbing ele- } \\
\text { ments will be introduced with great sensitivity and } \\
\text { risk-aware action.) }\end{array}$ & yes $(1) /$ no $(0)$ \\
\hline Does the song fit the image of the artist? & yes (1) / no (0) \\
\hline What do you feel when listening to the music? & $\begin{array}{l}\text { softness / intensity / unpleasantness / } \\
\text { pleasantness / solemnity / triviality }\end{array}$ \\
\hline How did you think/feel about the song? & original / novel / boring / varied \\
\hline
\end{tabular}

Source: Own representation.

Screening and evaluation of all songs happened within three sessions. A total of 68 students participated during the first session where 55 performances were presented. The second session contained of 55 clips, judged by 61 students. 56 songs were screened in session three with 50 students participating. At the beginning of each session, students who were previously unable to attend the event were asked to provide information about their socio-demographic characteristics. The different number of seminar participants (during each session) also explains the non-constant number of survey participants.

In order to be able to aggregate different (subjective) opinions, votes of the students were determined in each case: the estimate takes into account the voice of each individual student. Thus, a separate value was calculated for each variable and each song.

Performance characteristics, popularity of the artist and relationship between the several German States

In line with the literature of identifying factors defining the outcome of the Eurovision Song Contest (inter alia Ginsburgh \& Noury 2008; Spierdijk \& Vellekoop 2009; 
Budzinski \& Pannicke 2017a, 2017c), we determine several control variables that describe performance characteristics like gender (male, female), formation defined into a group, a (male-) soloist or a duo (male-male, male-female or female-female) formation, an opening-dummy-variable as well as an variable representing the order of performance (1 to 16). Furthermore, we create a host-dummy variable for controlling if the artist belongs to the host state of the contest and a dummy-variable if the artists already performed in the contest years before. ${ }^{3}$

Staying with the empirical literature and studies regarding song contests as a subject, we include numerous further control variables: because Budzinski \& Pannicke (2017a) found geographical preferences between the different 16 German states, we include variables about geographical relations of the Federal Republic of Germany. These variables are:

- a binary variable for neighboring states, if voters of German state A and performer B share a common border,

- a variable for the length of common border in $\mathrm{km}$,

- a variable for the total distance between the capitals of each German State,

- a binary variable for former Eastern parts of Germany, if performer B represents a German state that was a former Eastern part of Germany,

- a variable for patriotic voting, if voters of the German state A vote for their own German state A.

Budzinski \& Pannicke (2017a) also found dependencies between cultural relations between the German states and voting. Because the usually employed Hofstede's cultural dimensions (as in Ginsburgh \& Noury 2008) are not measurable for the German states, we follow Budzinski \& Pannicke (2017a) by considering the Big Five personality traits (neuroticism, extraversion, openness to experience, agreeableness, conscientiousness), which are correlated to Hofstede's cultural dimensions. Accordingly, we consider 5 different regional values of personality traits for each German state as a proxy for cultural characteristics.

3 Ten artists participated twice under the same stage name. 
Since researchers in behavioral economics find a relation between religion and economic agents' decisions (/annacconea 1998), we include a confession variable for all German states. The variable is coded as a dummy variable and takes value 1 if state A and state B share identical confession in relative terms. As in Budzinski \& Pannicke (2017a), we distinguish between Catholics, Protestants and those who are not relating to a religion. A German State is labeled as Catholics, Protestants or without religious affiliation if the membership is at least 40 percent.

In order to measure the artist's popularity, we collect data regarding the artist's former success and their media coverage. The latter data set is collected by searching LexisNexis (following e.g. Brandes et al. 2008) as well as Factiva databases for mentions of their band or stage name. Furthermore, we collect the performer's number of Google-hits to measure their current internet presence (Garcia-del-Barrio \& Pujol 2007; Prinz et al. 2012; Budzinski \& Pannicke 2017b). Former success is measured by counting the total number of official top 40 Charts (single and full album sales) plus their total number of weeks within these charts ${ }^{4}$ before the contest was broadcasted. We consider two time periods, a long-term ( 5 years before the contest took place) and a short-term (6 month before the contest took place) dataset. ${ }^{5}$

\subsection{Descriptive Statistics}

In order to get a first impression on the relation between objective and subjective quality dimensions and the total number of points, we look at the top 10 artists with the highest number of points within all contests throughout the years as well as the bottom 10 artists with the lowest number of points. While tables 3 and 4 show the top 10 artists and their (objective + subjective) quality characteristics, tables 5 and 6 summarize average data from each of the two quality dimensions.

The data was collected on: https://www.offiziellecharts.de/.

For detailed information see Budzinski \& Pannicke (2017b). 
Table 3: Objective dimensions, Top 10 by Points

\begin{tabular}{llllllllll}
\hline Year & Interpret & $\begin{array}{l}\text { Point } \\
\text { s }\end{array}$ & $\begin{array}{l}\text { Change } \\
\text { in har- } \\
\text { mony }\end{array}$ & $\begin{array}{l}\text { Highest } \\
\text { vocal } \\
\text { sounds }\end{array}$ & Bpm & $\begin{array}{l}\text { Chang } \\
\text { e in } \\
\text { speed }\end{array}$ & $\begin{array}{l}\text { Instru- } \\
\text { menta- } \\
\text { tion }\end{array}$ & $\begin{array}{l}\text { Intro_un- } \\
\text { der_10s }\end{array}$ & ABABCB \\
\hline 2014 & Revolverheld & 180 & no & Yes & 84 & no & no & yes & no \\
2009 Peter Fox & 174 & no & Yes & 84 & no & no & yes & no \\
2012 XAVAS & 172 & no & Yes & 80 & no & yes & yes & no \\
2015 Mark Forster & 170 & no & Yes & 82 & no & yes & yes & no \\
2010 Unheilig & 164 & no & Yes & 108 & no & yes & yes & no \\
2005 Juli & 159 & no & Yes & 104 & no & yes & yes & yes \\
2013 Bosse & 153 & no & Yes & 96 & no & yes & yes & no \\
2010 Silly & 152 & no & Yes & 88 & no & yes & no & yes \\
2006 Seeed & 151 & no & Yes & 112 & no & no & yes & yes \\
2007 Oomph! & 147 & no & Yes & 116 & no & yes & yes & yes \\
\hline Average in $\%$ & & 0 & 100 & 95.4 & 0 & 70 & 90 & 40 \\
\hline
\end{tabular}

Source: Own representation.

It can be seen in table 3 that all top 10 artists have the highest vocal sounds in their chorus and no changes in speed as well as in harmony. The tempo of the song is between a range of 80 and $110 \mathrm{bpm}$, exactly $95.4 \mathrm{bmp}$ on average. Almost every artist's running time of the intro is less than 10 seconds (except one). Interestingly, only $40 \%$ of the song's compositions are based on the scheme ABABCB. 
Table 4: Objective dimensions, Bottom 10 by Points

\begin{tabular}{|c|c|c|c|c|c|c|c|c|c|}
\hline Year & Interpret & Points & $\begin{array}{l}\text { Change } \\
\text { in har- } \\
\text { mony }\end{array}$ & $\begin{array}{l}\text { Highest } \\
\text { vocal } \\
\text { sounds }\end{array}$ & Bpm & $\begin{array}{l}\text { Chang } \\
\text { e in } \\
\text { speed }\end{array}$ & $\begin{array}{l}\text { Instru- } \\
\text { menta } \\
\text { tion }\end{array}$ & $\begin{array}{ll}\text { In- } \\
\text { a- } \\
\text { tro_un- } \\
\text { der_10s }\end{array}$ & $\begin{array}{l}A B A- \\
B C B\end{array}$ \\
\hline 2007 & $\begin{array}{l}\text { Kalle feat. } \\
\text { M.A.R.S. Allstars }\end{array}$ & 10 & no & yes & 72 & no & yes & no & no \\
\hline 2014 & Kitty Kat & 10 & no & yes & 69 & no & yes & yes & no \\
\hline 2005 & $\begin{array}{l}\text { Mamadee feat. } \\
\text { Gentleman }\end{array}$ & 10 & no & yes & 63 & no & yes & yes & no \\
\hline 2005 & $\begin{array}{l}\text { Sandy Mölling } \\
\text { feat. Manuellsen }\end{array}$ & 10 & no & yes & 108 & no & yes & yes & no \\
\hline 2014 & Sebastian Hackel & 10 & no & yes & 72 & no & yes & no & no \\
\hline 2013 & Guaia Guaia & 8 & no & yes & 100 & no & no & yes & no \\
\hline 2012 & $\begin{array}{l}\text { Mellow Mark feat. } \\
\text { Nina Maleika }\end{array}$ & 8 & no & yes & 100 & no & no & yes & no \\
\hline 2006 & AK4711 & 6 & no & no & 100 & no & no & yes & no \\
\hline 2010 & $\begin{array}{l}\text { Bernd Begemann } \\
\text { \& Dirk Darmstaed- } \\
\text { ter }\end{array}$ & 4 & no & yes & 144 & no & no & yes & yes \\
\hline \multirow[t]{2}{*}{2015} & Wunderkynd & 2 & no & yes & 152 & no & yes & no & no \\
\hline & Average in \% & & 0 & 90 & 98 & 0 & 60 & 70 & 10 \\
\hline
\end{tabular}

Source: Own representation.

Very similar to above, no song of the bottom 10 artists has a change in harmony or a change in speed (see table 4). Almost every artist has the highest vocal sound in the chorus. On average, $70 \%$ of the running time of the intro is less than 10 seconds. Remarkably, only $10 \%$ of the song's compositions are based on the scheme ABABCB. Table 5 shows a comparison between the top and bottom 10 artists and how they perform in the different objective quality dimensions. 
Table 5: Comparison between objective quality dimensions on average, Top and Bottom 10 artists

\begin{tabular}{l|l|l|l}
\hline Objective Dimensions & \multicolumn{2}{c}{ Average: Top 10 } & \multicolumn{2}{l}{ Average: Bottom 10 } & $\begin{array}{l}\text { Difference (percen- } \\
\text { tage points) }\end{array}$ \\
\hline Change in harmony & $0 \%$ & $0 \%$ & 0 \\
Highest vocal sounds & $100 \%$ & $90 \%$ & 10 \\
Bpm & 95,4 & 98 & 2.6 \\
Change in speed & $0 \%$ & $0 \%$ & 0 \\
Instrumentation & $70 \%$ & $60 \%$ & 10 \\
Intro_under_10s & $90 \%$ & $70 \%$ & 20 \\
Composition ABABCB & $40 \%$ & $10 \%$ & 30 \\
\hline
\end{tabular}

Source: Own representation.

As demonstrated in table 5, the differences in their appraisal on average do not vary expressively. Likewise, table 6 shows a comparison between the top and bottom 10 artists and how they perform in the different subjective quality dimensions.

Table 6: Comparison between average subjective quality dimensions, Top and Bottom 10 artists

\begin{tabular}{|c|c|c|c|}
\hline Subjective Dimensions & Average: Top 10 & Average: Bottom 10 & $\begin{array}{l}\text { Difference (percentage } \\
\text { points) }\end{array}$ \\
\hline confident voice & $47 \%$ & $55 \%$ & -8 \\
\hline charismatic $\&$ authentic & $38 \%$ & $49 \%$ & -11 \\
\hline stylistically closed & $54 \%$ & $62 \%$ & -8 \\
\hline fit the image & $69 \%$ & $72 \%$ & -3 \\
\hline softness & $26 \%$ & $12 \%$ & 14 \\
\hline intensity & $23 \%$ & $26 \%$ & -3 \\
\hline unpleasantness & $23 \%$ & $25 \%$ & -2 \\
\hline pleasantness & $7 \%$ & $11 \%$ & -4 \\
\hline solemnity & $5 \%$ & $11 \%$ & -6 \\
\hline triviality & $12 \%$ & $15 \%$ & -3 \\
\hline boring & $64 \%$ & $51 \%$ & +13 \\
\hline original & $17 \%$ & $27 \%$ & -10 \\
\hline novel & $8 \%$ & $10 \%$ & -2 \\
\hline varied & $10 \%$ & $11 \%$ & -1 \\
\hline
\end{tabular}

Source: Own representation. 
This is a rather interesting outcome, since the bottom 10 performers achieve in almost every dimension more approval on average.

\subsection{Analytical Statistics}

The results of the three models we estimated are presented in table 9 (Appendix). Tables 7 and 8 summarize the estimations of the relationship between the objective and subjective quality dimensions and the points that the contestants achieved in the music competition. The regression output from different model specifications are presented including a variety of combinations of explanatory variables explained previously in equation 1 . Since each of the three models has its virtues and shortcomings, we compiled tables 7 and 8 by writing significant if all three models show significant results, significant (2) if two out of 3 models expose significant results and the third model does not depart in terms of sign, and insignificant if no or just one model display significant results. The terms positive and negative refer to the sign of the significant results. In one case, we put the entry in brackets (change in speed) because, while two models yield significance with a positive sign, one displays a not significant result with a negative sign.

\section{Table 7: Comparison of the estimations results, objective dimensions}

\begin{tabular}{ll}
\hline Objective Dimensions & Significance \\
\hline change in harmony & not significant \\
highest vocal sounds & not significant \\
bpm & not significant \\
change in speed & (positive significant) \\
instrumentation & not significant \\
intro_under_10s & positive significant \\
composition ABABCB & positive significant \\
\hline
\end{tabular}

Source: Own representation. 
Table 8: Comparison of the estimations results, subjective dimensions

\begin{tabular}{ll}
\hline Subjective Dimensions & Significance \\
\hline confident voice & negative significant (2) \\
charismatic \& authentic & positive significant \\
stylistically closed & negative significant \\
fit the image & positive significant (2) \\
softness & not significant \\
intensity & positive significant (2) \\
unpleasantness & positive significant (2) \\
pleasantness & negative significant (2) \\
solemnity & negative significant (2) \\
triviality & positive significant \\
boring & negative significant (2) \\
original & negative significant \\
novel & not significant \\
varied & not significant \\
\hline
\end{tabular}

Source: Own representation.

Table 7 shows that among the objective quality dimensions, short intros under 10 seconds as well as a composition scheme $A B A B C B$ positively influence success in the music contest. We are reluctant to interpret the results for change in speed since here the results of the zero-inflated model considerably departs from the other models. The implications for music complexity as a quality dimension are somewhat mixed. Short intros and sticking to a simple composition scheme point more to simplicity being factors that are boosting success in the dataset. However, other complexity dimensions like change in harmony and instrumentation as well as factors like moderate bpm and highest vocal sounds in the chorus do not have a significant influence on the success of a song. Altogether, the predictions of music theory are to a considerable extent not supported by our analysis.

Interestingly, many more of the subjective quality dimensions display a significant correlation with success (table 8). In particular, a charismatic \& authentic performance and triviality of a song have a significant positive impact on success in our sample. While not being on the statistical significance level in all of our model specifications, fit the image, intensity, and unpleasantness also display a clear pattern of 
positive correlation with success. Although softness also yields a significant positive correlation in the zero-inflated model, we are reluctant to interpret this result as it does not show stable significant results in the other model specifications. The dimensions stylistically closed performance and originality are negatively significant throughout all specifications with confident voice, pleasantness, solemnity, and boring displaying negatively significant correlations in the majority of specifications. In contrast, the dimensions novel and varied are not significant for success. So, while several subjective quality dimensions perform as music theory predicts in our sample (charismatic \& authentic performance; fit the image; boring), we receive contradictory results for confident voice and pleasantness.

\section{Discussion and Conclusion}

So, does quality matter for audience voters in a music contest? According to our dataset, the answer is both yes and no. Different dimensions of quality exert different influences on the voting results of the audience. This supports the notion of quality being a complex, multi-dimensional phenomenon and demonstrates the value of our approach to disentangle quality into a (probably incomplete) number of quality-related dimensions. As such, our contribution points to a fruitful area of further research.

However, the results of our empirical study are also directly interestingly. With respect to the objective dimensions, the significant results are rather intuitive. A short intro and a standard composition scheme $A B A B C B$ increases the quality as perceived by the (majority of the) audience and, thus, significantly improves the probability of success in the music competition. This is probably true because the listeners are so used to the standard scheme and a short intro ensures a quick start to the song. These results are also partly consistent with the significant results regarding the subjective dimensions. For example, the originality of pieces has a significant negative impact with novelty and variety showing no significant influence on success. This is probably precisely because the majority of listeners enjoy more familiar pieces of music and, therefore, consider them to be of higher perceived quality. This effect of habit also seems to superimpose all the other objective parameters, i.e. a change of harmony, the highest tone in the chorus, the speed of the piece, a tempo change 
and the instrumentation, which do not appear to be very relevant to the voters in the song contest (i.e. these parameters are all insignificant).

With regard to the results in terms of subjective quality dimensions, here too some of the results can be described as being intuitive. This includes that an authentic and charismatic performance correlates significantly positively with the result in the music contest. Also, that a song, which fits the image of the artists provides a better, more harmonious performance for the audience and, thus, performs better does not really surprise. A more emotional experience is provided by the category unpleasantness because a dramatic, exciting, stirring song touches the listener and, therefore, a better performance, a significant positive correlation, can be explained (although music theory may conjecture otherwise). Eventually, the significant positive relationship between the dimension triviality and the competition result continues the storyline of the objective dimensions: listeners obviously prefer more uncomplicated (trivial) pieces, which they are accustomed to, over tricky, novel/original/varied - in that sense ambitious and challenging - compositions. The preference for known qualities over unknown qualities due to risk-aversion of consumers is also well-known from the economics of (music) superstars (MacDonald 1988). Another result is that boring pieces have a significant negative impact on contest success and, thus, represent lower quality in the eyes of the audience, which is not really surprising and also rather intuitive.

Our empirical analysis of this special music contest also yields some unexpected results. For instance, the stylistically closed category has proven to be significantly negative. This result is surprising because the conjecture from music theory would rather be a positive sign. Especially when a performance is stylistically closed (singing, expression, acting, stage decoration, etc.; corporate identity), this should be considered a higher quality and lead to a better result. The same is true for the also significantly negative correlated variable pleasantness because - as already shown with other variables - the listeners presumably prefer simple and easy songs. However, there may just be too much of a good thing and if performances/songs are too trivial, too shallow and too well-known, they may be perceived as qualitatively worse by the majority of the audience. This could e.g. to apply to ballads that are classified by both the lyrics and the music as too cheesy. In that sense, both stylistically-closed and pleasant 
may come close to being boring in the eyes of the audience. However, an exact limit as to when a song is too cheesy cannot to be determined by our research. The criterion confident voice is also significantly negative correlated with the quality. This is true for at least two estimates. The result is surprising, because it is plausible to assume that a confident voice leads to a higher quality and thus to a better chance of competing. A confident voice should actually rate the listener as more beautiful compared to an unconfident voice. Again, one can only speculate about the result. Perhaps here too, with regard to the criterion boring, it can be seen that a voice without blemish, without roughness or smoke is perceived as boring and therefore there is a negative correlation to the quality. A similar interpretation could be made for the criterion solemnity, because this criterion is also significantly negative correlated with the quality. Maybe it is also here that a too festive, solemn song is considered too trivial and boring.

In summary, the analysis has shown that simple (but not too simple) pieces with a known structure that are presented authentically enjoy the highest probability to be successful in music contests determined by audience voting. For producers, artists, music managers, and contest organizers, this represents interesting and valuable knowledge. Of course, if the contest is determined by other mechanisms, like a jury of experts, our direct results may not apply because they may value other quality dimensions. However, disentangling different quality dimensions and distinguishing objective and subjective dimensions, as suggested in this paper, represents a promising way for new insights for other types of music contests as well. 


\section{Appendix}

Table 9: Fixed effects model (1), Poisson fixed effects model and Zero-inflated Poisson model (3), long term ${ }^{6}$

\begin{tabular}{llll}
\hline Variables & Model (1) & Model (2) & Model (3) \\
\hline Objective Dimensions & & & \\
change_harmony & -0.0253 & $0.131^{*}$ & -0.0386 \\
highest_vocal_sounds & 0.184 & $-0.0651^{*}$ & 0.0213 \\
bpm & 0.0904 & 0.00532 & 0.0411 \\
change_in_speed & $0.717^{*}$ & $0.319^{* * *}$ & -0.0185 \\
instrumentation & 0.164 & 0.00216 & -0.0521 \\
intro_<10s & $0.950^{* * *}$ & $0.244^{* * *}$ & $0.116^{* * *}$ \\
ABABCB & $1.541^{* * *}$ & $0.435^{* * *}$ & $0.217^{* * *}$
\end{tabular}

\section{Subjective Dimensions}

\begin{tabular}{llll} 
confident_voice & $-1.712^{* *}$ & $-0.431^{* * *}$ & -0.209 \\
charismatic_- & $3.757^{* * *}$ & $1.033^{* * *}$ & $0.887^{* * *}$ \\
closed_performance & $-5.400^{* * *}$ & $-1.099^{* * *}$ & $-1.462^{* * *}$ \\
fit_the_image & $4.439^{* * *}$ & $1.294^{* * *}$ & 0.245 \\
softness & 0.884 & -0.0737 & $0.672^{* * *}$ \\
intensity & $-1.762^{*}$ & $-0.568^{* *}$ & 0.241 \\
unpleasantness & $1.352^{*}$ & 0.119 & $0.590^{* * *}$ \\
pleasentness & -1.384 & $-0.985^{* * *}$ & $-0.871^{* * *}$ \\
solemnity & $-5.048^{* * *}$ & $-1.966^{* * *}$ & -0.273 \\
triviality & $3.509^{* *}$ & $1.603^{* * *}$ & $2.001^{* * *}$ \\
boring_ & $-2.944^{* *}$ & -0.405 & $-1.111^{* * *}$ \\
original & $-5.301^{* * *}$ & $-1.821^{* * *}$ & $-1.052^{* * *}$ \\
novel & -2.103 & -0.253 & $-0.954^{* *}$ \\
varied & -0.411 & 0.543 & -0.444 \\
\hline $\mathrm{N}$ & 2576 & 2576 & 2576 \\
\hline
\end{tabular}

${ }^{*} p<0.05,{ }^{* *} p<0.01,{ }^{* * *} p<0.001$

Source: Own representation.

6 We chose not to report and discuss control variables in this paper, although we control for them as described in section 4. Detailed estimation results for all variables can be obtained from the authors upon request. We run a OLS and Poisson model that leads to results that are very similar to those estimated. If the popularity variables are employed in their short term version, the estimation results for our quality variables do not effectively change. The results of the short-term estimations are on file with the authors. 


\section{References}

Adler, M. (1985), Stardom and Talent, in: American Economic Review 75: 208-212.

Adler, M. (2006), Stardom and Talent, in: V. A. Ginsburgh \& D. Throsby (eds), Handbook of the Economics of Art and Culture, Vol. 1, Amsterdam: Elsevier, 895-906.

Amegashie, J.A. (2009), American Idol: Should It Be a Singing Contest or a Popularity Contest, in: Journal of Cultural Economics 33(4): 265-277.

Andersen, E.B. (1970), Asymptotic Properties of Conditional Maximum-likelihood Estimators, in: Journal of the Royal Statistical Society B(32): 283-301.

Asai, S. (2008), Factors Affecting Hits in Japanese Popular Music, in: Journal of Media Economics 21(2): 97-113.

Bauer, C. \& Schedl, M. (2018), On the Importance of Considering Country-specific Aspects on the Online-Market: An Example of Music Recommendation Considering Country-Specific Mainstream, in: Proceedings of the 51st Hawaii International Conference on System Sciences: 3647-3656.

Biamonte, N. et al. (2011), Pop-Culture Pedagogy in the Music Classroom. Teaching Tools from American Idol to YouTube, Lanham: Scarecrow Press.

Biddle, J.E. \& Hamermesh, D.S. (1998), Beauty, Productivity, and Discrimination: Lawyers' Looks and Lucre, in: Journal of Labor Economics 16(1): 172-201.

Borghans, L. \& Groot, L. (1998), Superstardom and Monopolistic Power: Why Media Stars Earn more than their Marginal Contribution to Welfare, in: Journal of Institutional and Theoretical Economics 54: 546-571.

Brandes, L., Franck, E. \& Nüesch, S. (2008), Local Heroes and Superstars: An Empirical Analysis of Star Attraction in German Soccer, in: Journal of Sports Economics 9(3): 266-286.

Budzinski, O. \& Gaenssle, S. (2018), The Economics of Social Media Stars: An Empirical Investigation of Stardom, Popularity, and Success on YouTube, Ilmenau Economics Discussion Papers 23(112).

Budzinski, O. \& Pannicke, J. (2017a), Culturally-Biased Voting in the Eurovision Song Contest: Do National Contests Differ?, in: Journal of Cultural Economics 41(4): 343-378. 
Budzinski, O. \& Pannicke, J. (2017b), Does Popularity Matter in a TV Song Competition? - Evidence from a National Music Contest, Ilmenau Economics Discussion Papers 22(106).

Budzinski, O. \& Pannicke, J. (2017c), Do Preferences for Pop Music Converge across Countries - Evidence from the Eurovision Song Contest, in: Creative Industries Journal 10(2): 168-187.

Child, W. (2000), Monroe Beardsley's Three Dimensions for Aesthetic Value. A Neglected Resource in the Evaluation of Recent Music, in: Journal of Aesthetic Education 34(2): 49-63.

Chung, K. \& Cox, R. (1994), A Stochastic Model of Superstardom: An Application of the Yule Distribution, in: Review of Economics and Statistics 76: 771-775.

Clerides, S. \& Stengos, T. (2006), Love thy Neighbor, Love thy Kin: Voting Biases in the Eurovision Song Contest. Discussion Paper 01, University of Cyprus.

Cohrdes, C, Lehmann, M. \& Kopiez, R. (2012), Typikalität, Musiker-Image und die Musikbewertung durch Jugendliche, in: Musicae Scientiae 16: 81-101.

Crain, W. M. \& Tollison, R. (2002), Consumer Choice and the Popular Music Industry: A Test of the Superstar Theory, in: Empirica 29(1): 1-9.

Fenn, D., Suleman, O., Efstathiou, J. \& Johnson, N. (2006), How Does Europe Make Its Mind Up? Connections, Cliques and Compatibility between Countries in the Eurovision Song Contest, in: Physica A: Statistical Mechanics and its Applications 360(2): 576-598.

Ferreira, F. \& Waldfogel, J. (2013), Pop Internationalism: Has Half a Century of World Music Trade Displaced Local Culture? In: The Economic Journal 123: 634-664.

Filimon, N., López-Sintas, J. \& Padrós-Reig, C. (2011), A Test of Rosen's and Adler's Theories of Superstars, in: Journal of Cultural Economics 35: 137-161.

Flôres, R.G. Jr \& Ginsburgh, V. (1996), The Queen Elisabeth Musical Competition: How Fair Is the Final Ranking? In: Journal of the Royal Statistical Society 45: 97104.

Franck, E. \& Nüesch, S. (2007), Avoiding 'Star Wars': Celebrity Creation as Media Strategy, in: Kyklos 60(2): 211-230. 
Garcia-del-Barrio, P. \& Pujol, F. (2007), Hidden Monopsony Rents in Winner-take-all Markets: Sport and Economic Contribution of Spanish Soccer Players, in: Managerial and Decision Economics 28: 57-70.

Geiger, F. (2003), 'Innigkeit' und 'Tiefe' als komplementäre Kriterien der Bewertung von Musik, in: Archiv für Musikwissenschaft 60(4): 265-278.

Gergaud, O., Ginsburgh, V. \& Livat, F. (2012), Success of Celebrities: Talent, Intelligence or Beauty?, in: Economics Bulletin 32(4): 3120-3127.

Giles, D.E. (2006), Superstardom in the U.S. Popular Music Industry Revisited, in: Economics Letters 92(1): 68-74.

Giles, D.E. (2007a), Increasing Returns to Information in the U.S. Popular Music Industry, in: Applied Economics Letters 14(5): 327-331.

Giles, D.E. (2007b), Survival of the Hippest: Life at the Top of the Hot 100, in: Applied Economics 39(15): 1877-1887.

Ginsburgh, V. \& van Ours, J. (2003), Expert Opinion and Compensation: Evidence from a Musical Competition, in: American Economic Review 93: 289-296.

Ginsburgh, V. \& Noury, A.G. (2008), The Eurovision Song Contest: Is Voting Political or Cultural? In: European Journal of Political Economy 24(1): 41-52.

Giomo, C. (1993), An Experimental Study of Children's Sensitivity to Mood in Music, In: Psychology of Music 21: 141-162.

Glejser, H. \& Heyndels, B. (2001), Efficiency and Inefficiency in the Ranking in Competitions: The Case of the Queen Elizabeth Music Contest, in: Journal of Cultural Economics 25(2): 109-129.

Haan, M.A., Dijkstra, S.G. \& Dijkstra, P.T. (2005), Expert Judgment versus Public Opinion? Evidence from the Eurovision Song Contest, in: Journal of Cultural Economics 29(1): 59-78.

Hamermesh, D. S. \& Biddle, J. E. (1993), Beauty and the Labor Market. National Bureau of Economic Research.

Hamlen, W. (1991), Superstardom in Popular Music: Empirical Evidence, in: Review of Economics and Statistics 73: 729-33.

Hamlen,W. (1994), Variety and Superstardom in Popular Music, in: Economic Inquiry 32: 395-406. 
Hausman, J.A., Hall, B.H. \& Griliches, Z. (1984), Econometric Models for Count Data with an Application to the Patents-R\&D Relationship, in: Econometrica 52: 909938.

Heizler, O. \& Kimhi, A. (2012), Who Will Be Idol? The Importance of Social Networks for Winning on Reality Shows, in: Journal of Socio-Economics 41(1): 18-25.

Hu, M.C., Pavlicova, M. \& Nunes, E.V. (2011), Zero-inflated and Hurdle Models of Count Data with Extra Zeros: Examples from an HIV-risk Reduction Intervention Trial, in: The American Journal of Drug and Alcohol Abuse, 37(5): 367-375.

lannaccone, L.R. (1998), Introduction to the Economics of Religion, in: Journal of Economic Literature, Vol. XXXVI: 1465-1496.

Kokko, A. \& Tingvall P.G. (2012), The Eurovision Song Contest, Preferences and European Trade, Ratio Working Paper No. 183.

Kramarz, V. (2014), Warum Hits Hits werden. Erfolgsfaktoren der Popmusik; Eine Untersuchung erfolgreicher Songs und exemplarischer Eigenproduktionen, Bielefeld: transcript Verlag.

Krueger, A.B. (2005), The Economics of Real Superstars: The Market for Rock Concerts in the Material World, in: Journal of Labor Economics 23(1): 1-30.

Lee, J. (2009), American Idol: Evidence on Same-Race Preferences, in: The B.E. Journal of Economic Analysis \& Policy 9(1), doi.org/10.2202/1935-1682.2134.

Leibenstein, H. (1950), Bandwagon, Snob, and Veblen Effects in the Theory of Consumers' Demand, in: Quarterly Journal of Economics 64(2): 183-207.

Lord, D., Washington, S.P. \& Ivan, J.N. (2005), Poisson, Poisson-gamma and Zeroinflated Regression Models of Motor Vehicle Crashes: Balancing Statistical Fit and Theory, in: Accident Analysis \& Prevention 37(1): 35-46.

MacDonald, G. (1988), The Economics of Rising Stars, in: American Economic Review 78: 155-166.

Mantzaris, A.V., Rein, S. R. \& Hopkins, A.D. (2018a), Examining Collusion and Voting Biases Between Countries During the Eurovision Song Contest Since 1957, in: Journal of Artificial Societies and Social Simulation 21(1): 1-13.

Mantzaris, A.V., Rein, S. R. \& Hopkins, A.D. (2018b), Preference and Neglect amongst Countries in the Eurovision Song Contest, in: Journal of Computational Social Science, forthcoming. 
Pannicke, J. (2016), Abstimmungsverhalten im Bundesvision Song Contest: Regionale Nähe versus Qualität der Musik, in: Zeitschrift für Kulturmanagement: Kunst, Politik, Wirtschaft und Gesellschaft 2(2): 39-66.

Pannicke, J. (2018), The Economics of Entertainment, Frankfurt a.M.: Lang Dissertation.

Palmgren, J. (1981), The Fisher Information Matrix for Log Linear Models Arguing Conditionally on Observed Explanatory Variable, in: Biometrika 68(2): 563-566.

Prinz, J., Weimar, D. \& Deutscher, C. (2012), Popularity Kills the Talentstar? Einflussfaktoren auf Superstargehälter in der NBA, in: Zeitschrift für Betriebswirtschaft 82(7-8): 789-806.

Riedermann, F. (2012), Computergestützte Analyse und Hit-Songwriting, in: Black box pop. Analysen populärer Musik: 43-56.

Rooksby, R. (2003), How to Write Songs on Guitar, Bonn: Voggenreiter.

Rosen, S. (1981), The Economics of Superstars, in: American Economic Review 71(5): 845-858.

Tsay, C.J. (2013), Sight over Sound in the Judgment of Music Performance, in: Proceedings of the National Academy of Sciences 110(36): 14580-14585.

Schmidt, A. \& Terhag, J. (2010), Songwriting. 40 Wege zum eigenen Song, Mainz: Schott.

Schulze, G.G. (2003), Superstars, in: R. Towse (ed.), Handbook of Cultural Economics, Cheltenham: Elgar, 431-436.

Spierdijk, L. \& Vellekoop, M. (2009), The Structure of Bias in Peer Voting Systems: Lessons from the Eurovision Song Contest, in: Empirical Economics 36(2): 403425.

Stigler, G. \& Becker, G. (1977), De Gustibus Non Est Disputandum, in: American Economic Review 67(1): 76-90.

Thamm, K. (2012), Auswertung von Zähldaten mit wiederholten Beobachtungen pro Objekt: dargestellt an Beispielen aus dem landwirtschaftlichen Versuchswesen, Doctoral dissertation, Universitäts-und Landesbibliothek Sachsen-Anhalt.

Von Appen, R. (2007), Der Wert der Musik. Zur Ästhetik des Populären, Bielefeld: transcript Verlag. 
Yair, G. (1995), 'Unite Unite Europe': The Political and Cultural Structures of Europe as Reflected in the Eurovision Song Contest, in: Social Networks 17(2): 147 


\section{Diskussionspapiere aus dem Institut für Volkswirtschaftslehre der Technischen Universität IImenau}

Nr. 69 Budzinski, Oliver: Empirische Ex-Post Evaluation von wettbewerbspolitischen Entscheidungen: Methodische Anmerkungen, Januar 2012.

Nr. 70 Budzinski, Oliver: The Institutional Framework for Doing Sports Business: Principles of EU Competition Policy in Sports Markets, January 2012.

Nr. 71 Budzinski, Oliver; Monostori, Katalin: Intellectual Property Rights and the WTO, April 2012.

Nr. 72 Budzinski, Oliver: International Antitrust Institutions, Juli 2012.

Nr. 73 Lindstädt, Nadine; Budzinski, Oliver: Newspaper vs. Online Advertising - Is There a Niche for Newspapers in Modern Advertising Markets?

Nr. 74 Budzinski, Oliver; Lindstädt, Nadine: Newspaper and Internet Display Advertising - Co-Existence or Substitution?, Juli 2012b.

Nr. 75 Budzinski, Oliver: Impact Evaluation of Merger Control Decisions, August 2012.

Nr. 76 Budzinski, Oliver; Kuchinke, Björn A.: Deal or No Deal? Consensual Arrangements as an Instrument of European Competition Policy, August 2012.

Nr. 77 Pawlowski, Tim, Budzinski, Oliver: The (Monetary) Value of Competitive Balance for Sport Consumers, Oktober 2012.

Nr. 78 Budzinski, Oliver: Würde eine unabhängige europäische Wettbewerbsbehörde eine bessere Wettbewerbspolitik machen?, November 2012.

Nr. 79 Budzinski, Oliver; Monostori, Katalin; Pannicke, Julia: Der Schutz geistiger Eigentumsrechte in der Welthandelsorganisation - Urheberrechte im TRIPS Abkommen und die digitale Herausforderung, November 2012.

Nr. 80 Beigi, Maryam H. A.; Budzinski, Oliver: On the Use of Event Studies to Evaluate Economic Policy Decisions: A Note of Caution, Dezember 2012.

Nr. 81 Budzinski, Oliver; Beigi, Maryam H. A.: Competition Policy Agendas for Industrializing Countries, Mai 2013. 
Nr. 82 Budzinski, Oliver; Müller, Anika: Finanzregulierung und internationale Wettbewerbsfähigkeit: der Fall Deutsche Bundesliga, Mai 2013.

Nr. 83 Doose, Anna Maria: Methods for Calculating Cartel Damages: A Survey, Dezember 2013.

Nr. 84 Pawlowski, Tim; Budzinski, Oliver: Competitive Balance and Attention Level Effects: Theore-tical Considerations and Preliminary Evidence, März 2014.

Nr. 85 Budzinski, Oliver: The Competition Economics of Financial Fair Play, März 2014.

Nr. 86 Budzinski, Oliver; Szymanski, Stefan: Are Restrictions of Competition by Sports Associations Horizontal or Vertical in Nature?, März, 2014.

Nr. 87 Budzinski, Oliver: Lead Jurisdiction Concepts Towards Rationalizing Multiple Competition Policy Enforcement Procedures, Juni 2014.

Nr. 88 Budzinski, Oliver: Bemerkungen zur ökonomischen Analyse von Sicherheit, August 2014.

Nr. 89 Budzinski, Oliver; Pawlowski, Tim: The Behavioural Economics of Competitive Balance: Implications for League Policy and Championship Management, September 2014.

Nr. 90 Grebel, Thomas; Stuetzer, Michael: Assessment of the Environmental Performance of European Countries over Time: Addressing the Role of Carbon, September 2014.

Nr. 91 Emam, Sherief; Grebel, Thomas: Rising Energy Prices and Advances in Renewable Energy Technologies, July 2014.

Nr. 92 Budzinski, Oliver; Pannicke, Julia: Culturally-Biased Voting in the Eurovision Song Contest: Do National Contests Differ?, December 2014.

Nr. 93 Budzinski, Oliver; Eckert, Sandra: Wettbewerb und Regulierung, März 2015.

Nr. 94 Budzinski, Oliver; Feddersen, Arne: Grundlagen der Sportnachfrage: Theorie und Empirie der Einflussfaktoren auf die Zuschauernachfrage, Mai 2015.

Nr. 95 Pannicke, Julia: Abstimmungsverhalten im Bundesvision Song Contest: Regionale Nähe versus Qualität der Musik, Oktober 2015.

Nr. 96 Budzinski, Oliver; Kretschmer, Jürgen-Peter: Unprofitable Horizontal Mergers, External Effects, and Welfare, October 2015. 
Nr. 97 Budzinski, Oliver; Köhler, Karoline Henrike: Is Amazon The Next Google?, October 2015.

Nr. 98 Kaimann, Daniel; Pannicke, Julia: Movie success in a genre specific contest: Evidence from the US film industry, December 2015.

Nr. 99 Pannicke, Julia: Media Bias in Women's Magazines: Do Advertisements Influence Editorial Content?, December 2015.

Nr. 100 Neute, Nadine; Budzinski, Oliver: Ökonomische Anmerkungen zur aktuellen Netzneutralitätspolitik in den USA, Mai 2016.

Nr. 101 Budzinski, Oliver; Pannicke, Julia: Do Preferences for Pop Music Converge across Countries? - Empirical Evidence from the Eurovision Song Contest, Juni 2016.

Nr. 102 Budzinski, Oliver; Müller-Kock, Anika: Market Power and Media Revenue Allocation in Professonal Sports: The Case of Formula One, Juni 2016.

Nr. 103 Budzinski, Oliver: Aktuelle Herausforderungen der Wettbewerbspolitik durch Marktplätze im Internet, September 2016.

Nr. 104 Budzinski, Oliver: Sind Wettbewerbe im Profisport Rattenrennen?, Februar 2017.

Nr. 105 Budzinski, Oliver; Schneider, Sonja: Smart Fitness: Ökonomische Effekte einer Digitalisierung der Selbstvermessung, März 2017.

Nr. 106 Budzinski, Oliver; Pannicke, Julia: Does Popularity Matter in a TV Song Competition? Evidence from a National Music Contest, April 2017.

Nr. 107 Budzinski, Oliver; Grusevaja, Marina:Die Medienökonomik personalisierter Daten und der Facebook-Fall, April 2017.

Nr. 108 Budzinski, Oliver: Wettbewerbsregeln für das Digitale Zeialter - Die Ökonomik personalisierter Daten, Verbraucherschutz und die 9.GWB-Novelle, August 2017.

Nr. 109 Budzinski, Oliver: Four Cases in Sports Competition Policy: Baseball, Judo, Football, and Motor Racing, September 2017.

Nr. 110 Budzinski, Oliver: Market-internal Financial Regulation in Sports as an Anticompetitive Institution, October 2017.

Nr. 111 Bougette, Patrice; Budzinski, Oliver; Marty, Frédéric: EXPLOITATIVE ABUSE AND ABUSE OF ECONOMIC DEPENDENCE: WHAT CAN WE LEARN FROM THE INDUSTRIAL ORGANIZATION APPROACH?, December 2017. 
Nr. 112 Budzinski, Oliver; Gaenssle, Sophia: The Economics of Social Media Stars: An Empirical Investigation of Stardom, Popularity, and Success on YouTube, Januar 2018.

Nr. 113 Gaenssle, Sophia; Budzinski, Oliver; Astakhova Daria: Conquering the Box Office: Factors, influencing Success of International Movies in Russia, Mai 2018.

Nr. 114 Budzinski, Oliver; Stöhr, Annika: Die Ministererlaubnis als Element der deutschen Wettbewerbsordnung: eine theoretische und empirische AnaIyse, Juli 2018.

Nr. 115 Budzinski, Oliver; Kuchinke, Björn A.: Modern Industrial Organization Theory of Media Markets and Competition Policy Implications, September 2018.

Nr. 116 Budzinski, Oliver; Lindstädt-Dreusicke, Nadine: The New Media Economics of Video-on-Demand Markets: Lessons for Competition Policy, Oktober 2018.

Nr. 117 Budzinski, Oliver; Stöhr, Annika: Competition Policy Reform in Europe and Germany - Institutional Change in the Light of Digitization, November 2018.

Nr. 118 Budzinski, Oliver; Noskova, Victoriia; Zhang, Xijie: The Brave New World of Digital Personal Assistants: Benefits and Challenges from an Economic Perspective, December 2018.

Nr. 119 Bougette, Patrice; Budzinski, Oliver \& Marty, Frédéric: EXPLOITATIVE ABUSE AND ABUSE OF ECONOMIC DEPENDENCE: WHAT CAN WE LEARN FROM AN INDUSTRIAL ORGANIZATION APPROACH? [Updated Version 2018], December 2018.

Nr. 120 Bartelt, Nadja: Bundling in Internetmärkten - Ökonomische Besonderheiten, Wettbewerbseffekte und Regulierungsimplikationen, Dezember 2018.

Nr. 121 Budzinski, Oliver; Feddersen, Arne: Measuring Competitive Balance in Formula One Racing, März 2019. 